logos_i_ethos_2019_1_(49), s. 205-220

DOI: http://dx.doi.org/10.15633/lie.3442

\title{
Witold Nowak
}

https://orcid.org/0000-0002-3799-1851

Uniwersytet Rzeszowski

\section{Uczciwość, rzetelność, doskonałość}

W sztuce to, co najdoskonalsze

jest ledwie wystarczające

(J. W. Goethe)

Uczciwość i rzetelność to pojęcia nieobce procesowi twórczemu, a jeszcze bardziej jego społecznemu kontekstowi. Odbiorcy sztuki, a także sami artyści częstokroć stawiają pytania o uczciwość danego artysty, o autentyczność i szczerość jego wypowiedzi ${ }^{1}$. Także sam artysta bywa skłonny do zastanawiania się, czy jest uczciwy względem odbiorców swoich dzieł oraz względem siebie. Stawia sobie też pytania - a niekiedy musi odpowiedzieć innym na takie pytanie - o to, czy pracował rzetelnie, starannie, niepowierzchownie.

Uczciwość jest pojęciem z dziedziny moralności, gdzie oznacza cnotę, rzetelność - z dziedziny pracy i pragmatyki działania. W obszarze sztuki rzetelność to postawa artysty wobec swojej pracy. Oznacza znajomość artystycznego warsztatu i postępowanie zgodne z regułami zawodu, a także ogólną dokładność i dbałość o jakość roboty i jej wytworu². Rzetelnie

1 Zob. dyskusje przypadków dzieł artystów polskich i obcych w pracy A. Draguły, Bluźnierstwo. Między grzechem a przestępstwem, Warszawa 2013.

2 Zob. T. Kotarbiński, Traktat o dobrej robocie, Wrocław 1975. Przykładem próby powrotu w sztuce do doskonałości warsztatowej właściwej dawnym mistrzom jest twórczość - promowanych 
wykonane dzieło budzi szacunek, bo stoi za nim praca i znajomość warsztatu. Sytuacja ta odnosi się zarówno do dzieł sztuki wysokiej, jak i użytkowej. Dobrym przykładem tej ostatniej jest dawne wytwórstwo mebli, np. w epoce biedermeieru (1815-1848).

W epoce biedermeieru ebeniści wykonywali swą pracę rzetelnie i anonimowo, podążając torem rzemieślników średniowiecznych. Przestrzegali zasad funkcjonalności, stosowności i fachowości w wyborze materiału. Meble projektowali nie architekci, lecz sami wykonawcy. Smak estetyczny biedermeieru otaczało poczucie bezpieczeństwa, był on pozbawiony przepychu, czysto mieszczański: „To ów smak właśnie sprawiał, że życiu nie stawiano fałszywych wymagań, to on pozwalał cieszyć się zawsze przyjemną i miłą praktycznością. Ogromne zakłady przemysłowe nie zdołały wtedy jeszcze wchłonąć dumnej tradycji rzemiosła. Maszyna nie usuwała w cień indywidualnej pracy człowieka. Jeszcze nie uległ całkowitemu zerwaniu związek między sztuką a wszelkimi rodzajami rzemiosła artystycznego. Doceniano czysto techniczny podział pracy i wiedziano, jakiej go poddać ocenie. Np. narzeczeni nie szperali w ogromnych magazynach, by spośród setek modeli sypialni i jadalni wybrać taki, który za najniższą cenę oferował najwięcej; najpierw bowiem pokazywano im materiał, z jakiego chciano wykonać meble, ażeby mogli się w pełni przekonać, iż drewno było suche, ponieważ składowano je wystarczająco długo"3.

Co się wprost tyczy wytwórstwa mebli, to: „Każdy mebel musiał być jak najpraktyczniejszy i najwygodniejszy, w jak najprzyjemniejszy sposób wychodząc naprzeciw upodobaniom użytkowników. Jako że nie stało pieniędzy, aby płacić za przedmioty zdobione, chciano przynajmniej móc radować się wybornym materiałem, pięknie żyłkowanym i prążkowanym fornirem, czystymi intarsjami i świetnym rzemiosłem. Chciano przynajmniej móc chwalić prostą i rozsądną konstrukcję mebli. Ponieważ

przez antypostmodernistycznie zorientowanego krytyka sztuki Donald Kuspita - kalifornijskich Nowych Dawnych Mistrzów (Ch. Arnold, W. Beckman, F. Scott Hess, K. Gunderson i in.).

${ }^{3}$ G. Herman, Człowiek biedermeieru (1913), przeł. Ł. Musiał, w: Spory o biedermeier, wybór, wstęp i opracowanie J. Kubiak, Poznań 2006, s. 68. 
ubrania i bielizna musiały starczyć na długo, zwracano uwagę na dobry i trwały materiał. Należało więc zawsze kupować towary wysokiej jakości. A ponieważ rzeczy zbędne nie istniały, wszystko kształtowało się zgodnie z wymogami życia, dopasowując się doń w jak najprostszy sposób”"

Uczciwość to jedna z głównych cnót biedermeieru. Rzetelnośćłączyła się z nią w sposób naturalny. Biedermeier to prostota, skromność, uczciwe ceny za rzetelnie wykonane rzeczy. Jest to także czas bardzo intymnych, niekiedy sentymentalnych więzi ludzi z przedmiotami. Świadczy o tym już samo zdobnictwo przedmiotów, w którym pełno emblematów przyjaźni, miłości, przemijalności. Przedmioty wplatano wtedy silnie w życie osobiste, wiązano $\mathrm{z}$ nimi emocje i uczucia, traktowano jako pamiątki chwil i wydarzeń oraz jako relikwie po ludziach dalekich lub zmarłych.

\section{Doskonałość}

Mówimy o doskonałym wzroku, doskonałym słuchu, choć rzadziej o doskonałej inteligencji. „Doskonała” może być walka bokserska lub mecz piłki nożnej. Mówimy o doskonałym dziele: pałacu, powieści, sonacie, komodzie, cukiernicy, fotografii. Doskonałe mogą być zegarek, koń, miecz. Jako doskonałe określane bywa wykonanie utworu muzycznego. Za doskonałe uchodzą perskie dywany bidżar, zwłaszcza bidżar takab, ze względu na ich piękno i trwałość. Opinię doskonałych mogą mieć całe wnętrza mieszkań bądź instytucji ${ }^{5}$. Mówimy o doskonałości moralnej, doskonałości estetycznej, a także o doskonałości ontologicznej i teologicznej. Wszystkie te określenia wskazują na osiągnięcie pewnej pozytywnej skrajności, dodatniego ultimum - na natężenie dodatnich jakości aż do uzyskania pełni, która budzi podziw i zachwyt.

4 G. Herman, Człowiek biedermeieru (1913), dz. cyt., s. 69-70.

5 Znakomitym fotografem wnętrz - jako przestrzennych elegii, gdy idzie o wnętrza dawne, a także siedlisk piękna, gdy idzie o współczesne - jest dziś Florentyńczyk Massimo Listri. Zob. M. Listri, Casa Bella, Udine 2011, passim; M. Listri, Grand Interiors, New York 2012, passim; M. Listri, Antiminimalist House, Torino 2007, passim. Nurt minimalizmu we wnętrzarstwie wynosi wyżej wnętrza ascetyczne, pozbawione dekoracyjności i licznych przedmiotów. 
Dążenie przez ludzi do doskonałości - w różnych dziedzinach - można uznać za stałą antropologiczną. Dążenie takie napotykamy bowiem we wszelkich kulturach, począwszy od najpierwotniejszych. U ludów pierwotnych jest to bazująca na przymiotach naturalnych doskonałość w walce lub ascezie ${ }^{6}$, w cywilizacjach rozwiniętych - doskonałość sztuk i urządzeń technicznych. Samo miasto uznawane bywa za doskonały twór człowieka ${ }^{7}$. Za budowle doskonałe uznawane były $-\mathrm{z}$ różnych względów - egipskie piramidy i gotyckie katedry; praca nad jednymi i drugimi wykraczała dalece poza jedno pokolenie, np. paryską katedrę Notre-Dame budowano przez 160 lat. Opinię przedmiotów doskonałych mają dziś produkty firmy Apple, choć wiele spośród nich spełnia skądinąd definicję gadżetü.

Klasyczną i wpływową definicję doskonałości dał Arystoteles w Metafizyce (ks. Delta V 16). Zrównał tam to, co doskonałe, z tym, co wykończone. Ściśle biorąc, znajdujemy u Stagiryty trzy pojęcia doskonałości: 1. doskonałe jest to, co zupełne, co zawiera wszystkie należne części; 2. doskonałe jest to, co jest tak dobre, iż w swoim rodzaju nie może być przewyższone; 3 . doskonałe jest to, co osiągnęło swój cel. Można uznać, iż pierwsze z wymienionych pojęć mieści się w drugim ${ }^{9}$. Dopiero trzecie rozumienie wnosi pewną rozbieżność i za tą rozbieżnością poszedł Tomasz z Akwinu, odróżniając dwa pojęcia doskonałości rzeczy: a) perfectio prima - gdy rzecz jest doskonała sama przez

6 Zob. prace zebrane w tomie Asceza. Odczłowieczenie czy uczłowieczenie, red. W. Słomka, Lublin 1985. Większość religii postuluje, aby ich wierni dążyli do doskonałości. Św. Augustyn podkreślał w polemice z Pelagiuszem dotyczącej łaski Bożej, iż wbrew tezom tego ostatniego osiągnięcie doskonałości nie jest w naszej mocy i że uzyskanie przez człowieka wysokiego poziomu moralnego nie przymusza Boga do udzielenia człowiekowi swojej łaski; ta ostatnia pozostaje zawsze wolnym darem Boga.

7 Dobrym przykładem są renesansowe projekty miast idealnych, np. projekty Leonarda da Vinci. Zob. P. Hall, Cities in Civilization. Culture, Innovation, and Urban Order, London 1998, s. 69-112.

8 Gadżet to przedmiot, który łudzi wartością dodaną, nakierowaną na osiągnięcie społecznego prestiżu oraz zbędnymi, czyli niepraktycznymi funkcjami.

9 Arystoteles, Metafizyka, przeł. K. Leśniak, ks. Delta V 16, 1021 b 12 n., w: Arystoteles, Dzieła wszystkie, t. 2, przekłady, wstępy i komentarze K. Leśniak, A. Paciorek, L. Regner, P. Siwek, Warszawa 1990, s. 703-704. 
się, doskonała w swej substancji, i b) perfectio secunda - gdy rzecz jest doskonała, bo doskonale służy swemu celowi ${ }^{10}$.

Formułowano jednak także koncepcje doskonałości, które - dla laika paradoksalnie - za warunek doskonałości uznawały niedoskonałość (Empedokles, Lucilio Vanini, Joseph J. Scaliger). W odniesieniu do świata zauważono, że gdyby był on doskonały, wtedy nie mógłby się ulepszać, rozwijać, podlegać postępowi - mówiono zatem, iżjest on doskonały przezswą niedoskonałość (perfectus propter imperfectionem). Gdyby świat był już tak doskonały, że nie mógłby podlegać rozwojowi i nie zostawałoby w nim miejsce na rzeczy nowe, wtedy nie miałby największej doskonałości ${ }^{11}$.

Należy pamiętać, że w sztuce idea doskonałości i dzieła doskonałego właściwa jest epoce przednowoczesnej, kiedy sztuka stanowiła imitatio naturae. Także pojęcie arcydzieła odnosi się zasadniczo do sztuki dawnej - przedkonceptualnej i przedperformatywnej - rządzonej przez zasadę mimesis ${ }^{12}$. Dzisiaj, gdy brak względnie jednoznacznych kryteriów oceny dzieł sztuki, trudno mówić o danym dziele jako arcydziele w sposób umożliwiający rzeczową estetyczną argumentację. Dlatego niektórzy sugerują bardzo subiektywną i mało satysfakcjonującą definicję arcydzieła: to dzieło, w kontakcie z którym odbiorca doznaje dreszczu afektacji.

W sztukach plastycznych teorie doskonałości jako - umożliwiającej rozwój lub swobodną grę wyobraźni odbiorcy - niedoskonałości należy łączyć z zasadą non finito, respektowaną np. przez Leonarda da Vinci. Zasada ta wywodzi się jeszcze z antyku, z filozofii Platona, dla którego dzieło sztuki nigdy nie jest zdolne do dokładnego odwzorowania wiecznych idei. Non finito jest rodzajem hołdu dla tej idei; oddaje ją także rzymska praktyka umieszczania po nazwisku-sygnaturze artysty słowa faciebat. W rzeźbie jej pionierem koncepcji i techniki non finito był Donatello, a spotykamy ją u Michała Anioła, Auguste’a Rodina i innych, którzy umyślnie nie wykańczali dzieł w całości lub w częściach.

10 św. Tomasz z Akwinu, Suma teologiczna, przełożył i objaśnieniami opatrzył o. P. Bełch OP, Londyn 1961, t. 1, s. 181.

11 Zob. W. Tatarkiewicz, O doskonałości, Warszawa 1976, s. 16-21.

12 E. Auerbach, Mimesis. Rzeczywistość przedstawiona w literaturze Zachodu, t. 1-2, przeł. i wstępem opatrzył Z. Żabicki, Warszawa 1968, passim. 
Ideę pozornego niewykończenia utworu dla wzmocnienia artystycznego efektu napotkamy również w literaturze. Powieść Zaburzenie (niem. Verstörung, 1967) Thomasa Bernharda kończy się bardzo długim monologiem księcia Sauraua. Książę jest ekscentrykiem i szaleńcem, jego monolog jest bezsensowny, mowa donikąd nie zmierza, jest jednak pełna pięknych fraz i interesujących skojarzeń. W pewnym momencie monolog się urywa, zupełnie nagle, zaskakując czytającego. A jednak właśnie to zakończenie i tym samym zakończenie całego dzieła pozostaje na długo w pamięci czytelnika. Jest to zakończenie w rodzaju literackiego non finito, które czyni powieść Bernharda dziełem „otwartym”, sugerującym wielkość świata i niemożność ujęcia go w językowe formuły ${ }^{13}$.

Innym paradoksem doskonałości jest to, że oznaczając skrajne natężenie pewnych jakości, bywa ona niekiedy odnoszona do jakości ujemnych. Już u Arystotelesa znajdujemy przykład doskonałego złodzieja, zaś Duns Szkot mówił o doskonałym oszuście i doskonałym oszczercy (perfectus calumniator). W literaturze napotkamy przykłady doskonałych łotrów, a w filmie takie postaci bardzo często pełnią rolę głównych bohaterów i motorów akcji. Natężenie cech, choćby złych, zawsze fascynowało ludzi, jest bowiem rzadko spotykane, trudne do podporządkowania pojęciu $\mathrm{w}$ jakiejś typologii, a także niewytłumaczalne ${ }^{14}$.

Osiągnięcie przez twórcę doskonałości w dziele czyni owo dzieło wzorczym. Nie oznacza to, że dzieło takie można naśladować w celu zrównania się z nim, ale że wskazuje ono kierunek działań artystycznych. Sytuacja jest tu podobna jak w przypadku doskonałości moralnej, która oznacza zrealizowanie pełni cnót i stanie się wzorem osobowym. Dzieło będące arcydziełem „wzywa” artystów do tworzenia dzieł dorównujących mu jakością artystyczną. Sam zaś artysta zaś oddziałuje jako wzór osobowy będący personifikacją duchowej wartości piękna ${ }^{15}$.

13 Zob. T. Bernhard, Zaburzenie, przeł. S. Lisiecka, Warszawa 2013.

14 Zob. M. Gołaszewska, Fascynacja złem. Eseje z teorii wartości, Warszawa 1994, s. 122-142. Jako portrecistę postaci skrajnie - zatem doskonale - złych autorka wymienia m.in. Louisa F. Celine’a.

$15 \mathrm{Na}$ temat artysty jako wzoru osobowego, czyli osobowej konkretyzacji wartości piękna zob. M. Scheler, Wzory i przywódcy, w: M. Scheler, Wolność, miłość, świętość. Pisma wybrane z filozofii religii, tłum. G. Sowiński, Kraków 2004. 
Doskonałość człowieka lub dzieła może wywoływać zazdrość, a także zawiść. Zazdrość taka staje się często motorem działania, gdyż budzi chęć dorównania komuś $\mathrm{w}$ dziele. $\mathrm{W}$ skrajnym natężeniu potrafi się jednak przekształcić w uczucie, które Max Scheler określił jako zazdrość egzystencjalną, czyli zazdrość o bycie tym kimś innym przy wzgardzeniu byciem sobą. Literacką ilustracją takiego przypadku wśród twórców jest powieść Przegrany (Der Untergeher, 1983) Bernharda. Tematem utworu jest dążenie do perfekcji w sztuce pianistycznej. Dwóch młodych pianistów, Wertheimer i narrator powieści, żywi zazdrość egzystencjalną względem najbardziej uzdolnionego trzeciego - Glenna Goulda. Obaj zdają sobie sprawę z przepaści, jaka dzieli ich zdolności od geniuszu Goulda, co w końcu sprawia, iż Wertheimer popełnia samobójstwo, zaś narrator sprzedaje fortepian i usiłuje napisać rozprawę o zmarłym Gouldzie ${ }^{16}$. Obaj zapomnieli jednak, że sztuka nie rodzi się ze sztuki, z prześcigiwania jednego dzieła lub wykonania przez inne, lecz z pochłonięcia rzeczywistością. Ich tragiczny los pokazuje, że dążenie do perfekcji nie jest najistotniejszym motywem sztuki.

\section{Dzieła doskonałe, arcydzieła}

Analiza dążenia do doskonałości w dziele wiedzie nas do problemu arcydzieł. Próbując zdefiniować arcydzieło, trudno na początku uniknąć - wobec współczesnego zamętu w tej kwestii - definicji innej niż historyczna. Za taką definicją podąża Harold Osborne w swym Oksfordzki słownik sztuki, przypominając, że w wiekach średnich nazwa ta odnosiła się do dzieła, dzięki któremu rzemieślnik, po ukończeniu kursu, osiągał stopień mistrzowski w cechu. W tym sensie arcydziełami nazwać można obrazy dyplomowe w Akademii Królewskiej ${ }^{17}$. Współcześnie termin „arcydzieło" stosowany jest do określenia

16 T. Bernhard, Przegrany, przeł. M. Kędzierski, Warszawa 2002.

17 Zob. Masterpiece, w: The Oxford Companion to Art, ed. H. Osborne, Oxford 1970, s. 702. 
nielicznych dzieł, w których osobowość wybitnego artysty znajduje swój najpełniejszy wyraz ${ }^{18}$.

Arcydziełem w sensie przednowoczesnym był zatem czeladniczy majstersztyk: miecz płatnerza, określony fragment witraża w wypadku witrażownika, świetny dzban konwisarza, ozdobna komoda stolarza, zamek z kluczem ślusarza ${ }^{19}$. Przedmiot ten miał być sprawdzianem umiejętności zawodowych członka cechu i warunkiem uzyskania tytułu mistrza cechowego. Termin wykonania majsterszyku był wyznaczany przez cech, przepisy ustalały też, jaki ma być charakter dzieła, np. jakie sceny $z$ historii świętej ma przedstawić malarz na obrazie, a także czy majstersztyk ma zostać sprzedany ${ }^{20}$.

Przejdźmy do przykładów arcydzieł w znaczeniu majstersztyków. Zacznijmy od ebenistyki. Tak zwana szafa Wrangla pochodząca $\mathrm{z}$ około 1566 roku, a znajdująca się dziś w Landesmuseum w Münster to przykład mebla zdobionego intarsją. Jakość intarsji wykorzystującej ornamenty zwojowe, stereometryczne wzory i perspektywiczne obrazy architektury - wszystko to sięga doskonałości. Motywem intarsji jest zamieranie i powolne budzenie się życia, a obrazowanie sugeruje, że autora projektu intarsji - której wykonawcą był prawdopodobnie snycerz z południowych Niemiec - należy szukać w kręgu takich artystów, jak Bosch, Bruegel, Floris

18 Termin ten występuje w nowszych krytykach sztuki rzadko. W wielkim wyborze tekstów krytycznych o sztuce Art in Theory 1900-2000. An Anthology of Changing Ideas, eds. Ch. Harrison, P. Wood, Oxford 2003 terminu masterpiece próżno szukać nawet w indeksie pojęć.

19 Gotyckie zamki z kluczami (których pióra, fr. a peigne, posiadały dużą liczbę równoległych i blisko rozmieszczonych nacięć) zwłaszcza przeznaczone dla kas ogniotrwałych, były mechanizmami dalece zawiłymi, których wykonanie jako chef d’oeuvre zabierało niekiedy dwa albo i więcej lat. Wskutek owej zawiłości posługiwanie się zamkami nie należało do łatwych. Zarazem stopień komplikacji mechanizmu zamka - stanowiącego czasem raczej osobliwość aniżeli praktyczny wytwór kunsztu rzemieślniczego - był odpowiednikiem dekoracyjnych motywów sztuki późnośredniowiecznej. „Przód zamka wykonanego jako majstersztyk - pisze Cahn - przypominał kościół gotycki, w świadomie archaizującym upodobaniu do takich wartości jak pomysłowość i zawiłość, unieśmiertelniając aż po wiek XVIII gotyk płomienisty" (W. Cahn, Arcydzieła. Studia z historii pojęcia, przeł. P. Paszkiewicz, Warszawa 1988, s. 38).

20 Zob. W. Cahn, Arcydzieła..., dz. cyt., s. 19-44. 
i Heemskerck ${ }^{21}$. Tradycyjna dwudzielność szafy została przełamana połączeniem obu stref pilastrami i kolumienkami, wykorzystano też szufladki, skrytki, nastawki i bogate zdobienia. Zarówno pomysł artystyczny, jak i robota ebenisty są najwyższej miary. Niemiecka staranność wykonania uczyniła z mebla prawdziwe dzieło sztuki. Szafa Wrangla to mebel ekskluzywny. Meble tego rodzaju i klasy nabywali głównie europejscy książęta.

Pozostając w kręgu majstersztyków, czyli sztuki częściowo użytkowej, lecz o najwyższych walorach artystycznych, zwróćmy uwagę na florencką mozaikę, zwaną pietra dura. Technika pietra dura wykorzystywana była głównie do zdobienia płyt stołowych i płytek przeznaczonych do wprawiania w sprzęty. Mozaikę z cienkich tafelek (łupku, białego lub czarnego marmuru, różnokolorowych kwarców albo półszlachetnych kamieni) układano w płaszczyźnie, według uprzedniego rysunku i starannie polerowano do połysku. Barwność kompozycji znacznie podnosiły starannie dobierane kolory, odcienie i żyłki. Obrazy powstające $\mathrm{w}$ technice pietra dura zawierały motywy florystyczne, martwe natury, sceny figuralne i krajobrazowe. Zdobienia tego rodzaju wykonywano od połowy XVI wieku, głównie we Florencji, a były one tak znakomite, że stanowiły jedną z największych atrakcji tego miasta i powód do jego odwiedzin przez podróżnych ${ }^{22}$. Najlepsze przedmioty wytworzone w technice pietra dura świadczą o tak wysokiej jakości warsztatu i artyzmu, iż wprawiają widza nie tylko w podziw, ale i w osłupienie. Są jako majstersztyki - doskonałe $\mathrm{w}$ tym sensie, że zdają się niemożliwe do przewyższenia w swoim gatunku.

Walter Cahn w swoim wnikliwym studium o historii idei arcydzieła przypomina, że pojęcie to stosowano początkowo do tworów architektury - jako najbardziej klasycznych i najtrwalszych spośród ludzkich wytworów - a dopiero później przeniesiono na takie obszary sztuki, jak

21 Zob. S. Hinz, Wnętrza mieszkalne i meble od starożytności po współczesność, przeł. B. Ostrowska, Warszawa 1980, s. 22-23.

${ }^{22}$ M. Wrześniak, Florencja - muzeum. Miasto i jego sztuka w oczach polskich podróżników, Kraków 2013, s. 53-87. 
malarstwo, literatura i muzyka ${ }^{23}$. Pojęcie arcydzieła i związana z nim terminologia (niem. Meisterstück, Meisterwerk, Hauptwerk, fr. chef d’oeuvre, ang. masterpiece, a wcześniej łac. mirabilium) mają długie i złożone dzieje, powiązane $\mathrm{z}$ filozofią i teologią oraz formułowanymi przez nie koncepcjami doskonałości i jej probierzy. Do tych ostatnich najczęściej zaliczano trwałość i uniwersalność, przy czym szybko zauważono, że arcydzieła oddziałują najczęściej z opóźnieniem.

W przednowoczesnych systemach ontoteologicznych napotykamy bardzo ważną ideę związaną z arcydzielnością - ideę Deus artifex. Zgodnie z tą ideą wywodzącą się z Platońskiego Timaiosa Bóg to wielki architekt, który stworzył świat $\mathrm{z}$ niczego i uformował go wedle swego wzoru. Porównanie pracy stwórczej Boga do pracy rzemieślnika - garncarza, krawca, hafciarza, kowala - najbardziej plastycznie i z największym upodobaniem wyraził św. Ambroży, biskup Mediolanu i nauczyciel św. Augustyna. Arcydziełem Boga był dla Ambrożego człowiek, dzielący z Bogiem przywilej myślenia, a zarazem istota o proporcjonalnym i pełnym wdzięku ciele. W Hexameronie czytamy: „Człowiek został odwzorowany przez Boga, swego artystę. Ma więc to szczęście, iż jest dziełem tak wybitnego rzemieślnika i malarza" ${ }^{24}$. W ciągu wieków średnich liczni autorzy - dając odpór konwencjonalnej mizoginii - za szczególnie udane, nieprześcignione $\mathrm{w}$ pięknie dzieło Boga uznawali kobietę ${ }^{25}$. Święty Augustyn, przyjmując za Biblią, że człowiek jest obrazem Boga (Rdz 1, 27), uznawał zarazem w swej psychologii duszę za obraz trójjedynego Boga. Zauważmy też długie trwanie idei Deus artifex, jako że jeszcze w Fauście Goethego napotykamy ideę człowieka jako „małego boga świata”, ideę która łączy w człowieku role mikrotheos i artifex.

${ }^{23}$ W. Cahn, Arcydzieła..., dz. cyt., s. 150n. Zawód architekta począł się cieszyć wielką estymą w wieku XIII. Za architektoniczne dzieła doskonałe uważano m.in. kościół-mauzoleum Małgorzaty Austriackiej w Brou i wieżę katedry w Strasburgu, dzieło Ulricha von Ensingen. Z kolei we wnętrzach katedr i kościołów czekały na widzów małe arcydzieła - zegary. Do najwybitniejszych należały zegary w Strasburgu, Pradze i Lyonie.

${ }^{24}$ Św. Ambroży, Hexameron I, c. VII, ad 25, cyt. za: W. Cahn, Arcydzieła..., dz. cyt., s. 47.

${ }^{25}$ Zob. W. Cahn, Arcydzieła..., dz. cyt., s. 54n. Na temat toposu i idei Deus artifex oraz paralelnej idei Natura artifex zob. też E. H. Curtius, Literatura europejska i łacińskie średniowiecze, tłum. i oprac. A. Borowski, Kraków 1997, s. 576-578. 
Ujmując rzecz systematycznie, należy powiedzieć, że arcydzieło jest dziełem szczytowym. Jest bezkonkurencyjne w tym sensie, że nie grozi mu degradacja wskutek pojawienia się nowych arcydzieł. Jest niezastępowalne, bezwzględnie autonomiczne. Emilia Basara-Lipiec w pracy poświęconej arcydziełom pisze: „Istota arcydzieła tkwi w jego wewnętrznej strukturze, zespalającej wszystkie składniki tematyczne i formalne w kompozycję o takiej doskonałości, iż - jako całość - wytwarza ono nową jakość aksjologiczną, nadbudowaną na układzie wartości zestrojonych, ale też wyodrębniającą się w fenomenie absolutności" ${ }^{26}$.

Choć arcydzieła nie są w żadnym sensie „mierzalne”, to same od swego pojawienia się stanowią w zbiorze wytworów sztuki miarę dla innych powstających dzieł. Po pierwsze, stają się układem odniesienia i wzorcotwórczej inspiracji dla nowo powstających dzieł. Tworzą kanon dzieł absolutnych, czyli sięgających wartości absolutnych. Po drugie, ich pojawienie się tworzy swoistą chronologię kultury, w której one same są głównymi punktami skali. Po trzecie, arcydzieła stają się miarą poziomu kultury danego czasu i społeczeństwa. Po czwarte, stanowią miarę zdolności twórczych gatunku ludzkiego i reprezentujących go indywidualności $\mathrm{ci}^{27}$.

Wśród innych, zadziwiających cech arcydzieł sytuuje się ich zdolność do „odkrywania” odbiorców, czyli sprawiania, że kontakt z arcydziełem czyni nas nowymi, pogłębionymi ludźmi. Oddziaływanie arcydzieła na odbiorców jest tajemnicze. Cechuje je swoiste promieniowanie związane z jakością, która klasyczna estetyka określała jako claritas. Przynależna dziełu claritas promieniuje w ten sposób, że oświetla nasze własne wnętrze i ujawnia $\mathrm{w}$ nim treści, których istnienia nie przeczuwaliśmy $^{28}$. W tym sensie arcydzieło oddziałuje niczym oświetlająca lampa, by posłużyć się metaforą Meyera $\mathrm{H}$. Abramsa ${ }^{29}$. Ale i więcej, bo

26 E. Basara-Lipiec, Arcydzieło. Teoria i rzeczywistość, Warszawa 1997, s. 31.

27 Zob. E. Basara-Lipiec, Arcydzieło..., dz. cyt., s. 32.

28 Zob. W. Stróżewski, Claritas: uwarunkowania historyczne i treść estetyczna pojęcia, „Estetyka” 2 (1961), s. 143.

29 Zob. M. H. Abrams, Zwierciadło i lampa. Romantyczna teoria poezji a tradycja krytycznoliteracka, przeł. M. B. Fedewicz, Gdańsk 2003, s. 69. 
arcydzieło nie tylko odkrywa coś we mnie jako podmiocie, nie tylko pogłębia moją subiektywność, lecz także pokazuje mi coś ważnego, co przynajmniej po części leży poza mną. W tym sensie arcydzieła są epifaniczne ${ }^{30}$.

Pozostając dziełem szczytowym, arcydzieło skłania do podziwu i „zagarnia”, „obejmuje” odbiorcę. Władysław Tatarkiewicz pisał o tym, że ludzie, dzieła sztuki, a nawet przedmioty mogą być wielkie i bliskie. Wielkie skłaniają do podziwu, bliskie - współgrają z naszymi najbardziej osobistymi uczuciami. „Wielkość i bliskość są dla człowieka w ciągu całego jego życia kategoriami jego widzenia, rozumienia, odczuwania świata" ${ }^{31}$. Są to kategorie ludzkiego świata; nie wykluczają się wzajemnie, ale też jedna nie pociąga za sobą drugiej. W odniesieniu do dzieł sztuki należy chyba stwierdzić, że arcydzieła nazbyt są wielkie, aby mogły stać się prawdziwie bliskie. Aura doskonałości, koneserskiego i społecznego podziwu, jaka je otacza, zdaje się wykluczać możliwość intymnego z nimi obcowania. Arcydzieła wcielają najwyższe wartości, które są podzielane przez tak wielu ludzi, że nie sposób „posiadać” ich dla siebie, jakkolwiek twórcy arcydzieł mogą nam być - jako ludzie - bardzo bliscy.

Zdaniem poważnych autorów w arcydziełach poza ich warsztatową jakością jest pewien trudno uchwytny element, który nie przynależy bezpośrednio do ich strony formalnej, technicznej, lecz który emanuje z całości dzieła. W tej perspektywie zrozumiały staje się spór o obraz Salvadora Dalego Chrystus św. Jana od Krzyża znany jako Ukrzyżowanie (1951), zakupiony - w atmosferze skandalu, który towarzyszy dziełu do dziś - do zbiorów sztuki miasta Glasgow wraz z prawami autorskimi do dzieła. Zdaniem niektórych obraz jest religijnym arcydziełem. Zdumiewająca perspektywa obrazu - naśladująca tę z zachowanego rysunku przypisywanego hiszpańskiemu mistykowi Janowi od Krzyża skłania do wielkiego uznania dla malarza, jednakże zdaniem wielu

${ }^{30}$ Koncepcję sztuki jako indywidualnej epifanii odnajdujemy dziś w pracach Ch. Taylora. Zob. jego Źródła podmiotowości. Narodziny tożsamości nowoczesnej, przeł. zespól, naukowo oprac. T. Gadacz, wstęp A. Bielik-Robson, Warszawa 2001, s. 837-909.

31 W. Tatarkiewicz, Wielcy i bliscy, w: W. Tatarkiewicz, O filozofii i sztuce, Warszawa 1986, s. 435. 
krytyków i artystów dziełu „brak ducha”, w tym ducha religijnego. Jest ono raczej mistrzowską sztuczką nakierowaną na wzbudzenie podziwu w widzach (i jako takie nosi znamiona kiczu) aniżeli obrazem religijnym, za jaki się podaje ${ }^{32}$. Prawdziwe arcydzieło jest bowiem wolne od manipulacji.

Pytając o to, czym jest ów „duch” dzieła, bez którego jest ono tylko płaskim i ledwie przemawiającym malowidłem, dobrze oddać głos samemu malarzowi. Eugène Delacroix w dzienniku opisał to tak: „Wracając pieszo zaszedłem do kościoła Saint-Roch na mszę o północy. Tłum tam zgromadzony, światła, jakiś uroczysty nastrój wreszcie - wszystko to sprawiło, że obrazy na ścianach wydały mi się szczególnie zimne i ckliwe. Jakże rzadki jest talent! Ile ciężkiej pracy włożono, aby zabazgrać te płótna, jak zmarnowano najpiękniejsze tematy religijne! Od wszystkich tych obrazów, wykonanych tak cierpliwie, a nawet tak zręcznie, przez tyle rozmaitych rąk i tyle szkół, żądam jednego choć dotknięcia, iskry uczucia i odrobiny prawdziwego wzruszenia, które ja ofiarowalbym im niemal bezwiednie. $W$ tej uroczystej chwili obrazy wydały mi się gorsze niż zazwyczaj; ale jak bardzo oczarowałaby mnie rzecz piękna!" ${ }^{33}$.

Jako przykład dzieła doskonałego Delacroix wymieniał w Dziennikach obraz Petera P. Rubensa Święty Benedykt, a dokładniej jeden jego motyw - białego konia tego świętego. Za dzieła doskonałe uznał także późne kwartety Josepha Haydna, wzmiankując o uwadze, jaką zawdzięcza Szopenowi, że taki poziom doskonałości dało Haydnowi doświadczenie $^{34}$. Tego ostatniego zaś, mówi, nie potrzebował Mozart, którego wiedza i natchnienie były na jednym poziomie.

Arcydzieła składają się na kanon najlepszych dzieł i jako takie stanowią rdzeń zbiorów muzeów sztuki. Warto dodać, że muzea Zachodu jako skarbnice arcydzieł mieszczą przeważnie wytwory artystów mężczyzn.

32 Zob. D. Ades, Dalí, London 2002, s. 178; Dalis Optical Illusions, ed. D. Ades, New HavenLondon 2000, s. 10-29.

33 E. Delacroix, Dzienniki. Część druga (1854-1863), przeł. J. Guze, J. Hartwig, Wrocław 1968, s. 392 .

34 Zob. E. Delacroix, Dzienniki. Czesść pierwsza (1822-1853), przeł. J. Guze, J. Hartwig, Wrocław 1968, s. 109 i 117. 
U podłoża tego stanu rzeczy leżą czynniki natury społecznej, wszak tworzenie sztuki było przez wieki domeną mężczyzn, a wiek Dawnych Mistrzów - czyli owe słynne kilka dekad około roku 1500 we Włoszech, które uchodzi za zenit sztuki Zachodu - współtworzyli niemal wyłącznie mężczyźni. Arcydzieła tworzone przez kobiety były w dawnych wiekach rzadkością, niekiedy dziełem arystokratek ekscentryczek, i dopiero dziś sytuacja dalece się $\mathrm{zmieniła}^{35}$.

$\mathrm{Na}$ koniec rzecz z punktu widzenia kulturowej i humanistycznej wartości sztuki najważniejsza, a mianowicie istnienie związku między arcydziełami i nadzieją. Arcydzieła wystawiają dodatnie świadectwo ludzkości. Równoważą w pewnym stopniu te dzieła człowieka, które wystawiają gatunkowi homo złe świadectwo: akty okrucieństwa, przemocy, wojny, wyzysku. Są zatem arcydzieła tym, co ludzkość mogłaby z nadzieją położyć na jednej z szal wagi podczas ostatecznego nad nią sądu. Po pierwsze, nadzieję budzi fakt, że znaczna część ludzi żyje życiem intensywnie twórczym, zmierzającym do najwyższych wartości. Po drugie, nadzieja bierze się stąd, że arcydzieła jako dzieła człowieka zdolne są sięgnąć do poziomu wartości absolutnych. Po trzecie, źródłem nadziei jest też fakt, że kolejne pokolenia ludzi skupiają uwagę na konkretyzowanych w arcydziełach sztuki wartościach najwyższych, że je autentycznie przeżywają i ogniskują wokół nich swą kulturę.

\section{Bibliografia}

Abrams M. H., Zwierciadło i lampa. Romantyczna teoria poezji a tradycja krytycznoliteracka, przeł. M. B. Fedewicz, Gdańsk 2003.

Ades D., Dalí, London 2002.

35 Zob. W. Chadwick, Kobiety, sztuka i społeczeństwo, przeł. E. Hornowska, Poznań 2015, passim. Ważną postacią kobiety-artystki w procesie przenoszenia splendoru z portretowanego władcy na artystę-portrecistę była Elisabeth Vigée-Lebrun, portrecistka królowej Francji Marii Antoniny. Artystka nie tylko świadomie zacierała na obrazie różnicę między królową a sobą, lecz w 1789 roku namalowała swój autoportret z córką w manierze przedstawień Madonny z Dzieciątkiem. Zob. też R. Parker, G. Pollock, Old Mistresses. Women, Art, and Ideology, London 1981, passim. 
Art in Theory 1900-2000. An Anthology of Changing Ideas, eds. Ch. Harrison, P. Wood, Oxford 2003.

Arystoteles, Dzieła wszystkie, t. 2, przekłady, wstępy i komentarze K. Leśniak, A. Paciorek,

L. Regner, P. Siwek, Warszawa 1990.

Asceza. Odczłowieczenie czy uczłowieczenie, red. W. Słomka, Lublin 1985.

Auerbach E., Mimesis. Rzeczywistość przedstawiona w literaturze Zachodu, t. 1-2, przeł. i wstępem opatrzył Z. Żabicki, Warszawa 1968.

Basara-Lipiec E., Arcydzieło. Teoria i rzeczywistość, Warszawa 1997.

Bernhard T., Przegrany, przeł. M. Kędzierski, Warszawa 2002.

Bernhard T., Zaburzenie, przeł. S. Lisiecka, Warszawa 2013.

Cahn W., Arcydzieła. Studia z historii pojęcia, przeł. P. Paszkiewicz, Warszawa 1988.

Chadwick W., Kobiety, sztuka i społeczeństwo, przeł. E. Hornowska, Poznań 2015.

Curtius E. H., Literatura europejska i łacińskie średniowiecze, tłum. i oprac. A. Borowski, Kraków 1997.

Dali's Optical Illusions, ed. D. Ades, New Haven-London 2000.

Delacroix E., Dzienniki. Część druga (1854-1863), przeł. J. Guze, J. Hartwig, Wrocław 1968.

Delacroix E., Dzienniki. Czesść pierwsza (1822-1853), przeł. J. Guze, J. Hartwig, Wrocław 1968.

Draguła A., Bluźnierstwo. Między grzechem a przestępstwem, Warszawa 2013.

Gołaszewska M., Fascynacja złem. Eseje z teorii wartości, Warszawa 1994.

Hall P., Cities in Civilization. Culture, Innovation, and Urban Order, London 1998.

Hinz S., Wnętrza mieszkalne i meble od starożytności po wspótczesność, przeł. B. Ostrowska, Warszawa 1980.

Kotarbiński T., Traktat o dobrej robocie, Wrocław 1975.

Listri M., Anti-minimalist House, Torino 2007.

Listri M., Casa Bella, Udine 2011.

Listri M., Grand Interiors, New York 2012.

Masterpiece, w: The Oxford Companion to Art, ed. H. Osborne, Oxford 1970, s. 702.

Parker R., Pollock G., Old Mistresses. Women, Art, and Ideology, London 1981.

Scheler M., Wolnossć, miłość, świętossć. Pisma wybrane z filozofii religii, tłum. G. Sowiński, Kraków 2004.

Spory o biedermeier, wybór, wstęp i opracowanie J. Kubiak, Poznań 2006.

Stróżewski W., Claritas: uwarunkowania historyczne i treść estetyczna pojęcia, „Estetyka” 2 (1961), s. 125-146.

Tatarkiewicz W., O doskonałości, Warszawa 1976. 
Tatarkiewicz W., O filozofii i sztuce, Warszawa 1986.

Wrześniak M., Florencja - muzeum. Miasto i jego sztuka w oczach polskich podróżników, Kraków 2013.

\section{Abstrakt}

\section{Uczciwość, rzetelność, doskonałość}

Artykuł jest próbą uporządkowania zagadnień uczciwości, rzetelności i arcydzieła w sztuce. Wychodzę od rozjaśnienia relacji między uczciwością, rzetelnością i doskonałością. Następnie prezentuję dzieje kategorii arcydzieła. Początki terminu „arcydzieło” sięgają pojęć średniowiecznych: fr. chef d’oeuvre, niem. Meisterstück i ang. masterpiece. $\mathrm{W}$ epoce oświecenia, a potem $\mathrm{w}$ romantyzmie termin ten uzyskał swoje wieloaspektowe znaczenie. Często używa się go wobec tych dziel sztuki, które są potężnymi ekspresjami twórczej osobowości artysty.

\section{Słowa kluczowe}

uczciwość, doskonałość, arcydzieło, twórczość, rzeczy, kultura materialna

\section{Abstract}

\section{Honesty, diligence, excellence}

The article is an attempt to put in order the problems of honesty, diligence and masterpiece in art. First, the relation between honesty, diligence and excellence is explained. Then, the history of the category of masterpiece is presented. The origin and development, including the shaping of the sense and scope of the term "masterpiece" goes back to medieval notions: French "chef doeuvre," German "Meisterstück" and English "masterpiece." In Enlightenment and especially in Romanticism it reaches the modern multiaspect approach. It is often used to works of art, which are the powerful expressions of the creative personality of an artist.

\section{Keywords}

honesty, excellence, masterpiece, creativity, things, material culture 